\title{
Unusual Ring Opening of Hexamethyl Dewar Benzene in Its Reaction with Triosmium Carbonyl Cluster
}

\author{
Wen-Yann Yeh* and Yu-Chiao Liu \\ Department of Chemistry, National Sun Yat-Sen University, Kaohsiung, Taiwan 804 \\ Shie-Ming Peng and Gene-Hsiang Lee \\ Department of Chemistry, National Taiwan University, Taipei, Taiwan 106
}

Received April 15, 2003

Summary: $\mathrm{Os}_{3}(\mathrm{CO})_{10}(\mathrm{NCMe})_{2}$ catalyzes the transformation of hexamethyl Dewar benzene(HMDB) to hexamethyl benzene (HMB). This catalytic reaction is in competition with ring opening of the HMDB ligand to give ( $\mu$ $\mathrm{H})_{2} \mathrm{Os}_{3}(\mathrm{CO})_{9}\left(\mu-\eta^{3}-\mathrm{CH}\left(\mathrm{C}_{6} \mathrm{Me}_{3}\right)\right)(\mathbf{1})$ and $(\mu-\mathrm{H}) \mathrm{Os}_{3}(\mathrm{CO})_{9}\left(\mu_{3}-\right.$ $\left.\eta^{2}-\mathrm{C} \equiv \mathrm{C}\left(\mathrm{C}_{4} \mathrm{Me}_{4} \mathrm{Et}\right)\right)(\mathbf{2})$.

The coordination chemistry of strained hydrocarbons has fascinated chemists striving to understand the details of structure and reactivity. ${ }^{1}$ In particular, benzene is rich with high-energy strained isomers, such as Dewar benzene, prismane, and benzvalene, which interconvert through complex and mysterious rearrangements. ${ }^{2}$ The unsubstituted Dewar benzene is shortlived. ${ }^{3}$ On the other hand, the hexamethyl Dewar benzene (HMDB) derivative is relatively stable and is prepared conveniently, ${ }^{4}$ which makes it the favorite substance for investigation of the Dewar ring system. ${ }^{5}$ Thermal conversion of HMDB to hexamethyl benzene $(\mathrm{HMB})$ has a measured activation energy of $37 \mathrm{kcal} / \mathrm{mol}$ and a half-life of $3 \mathrm{~h}$ at $150^{\circ} \mathrm{C}$, despite being exothermic by nearly $60 \mathrm{kcal} / \mathrm{mol}$ due to the ring strain and aromaticity. ${ }^{6}$ The high activation energy has been attributed in part to the symmetry forbiddenness of the thermal rearrangement. ${ }^{7}$

Metal-assisted rearrangement of HMDB to HMB is known. For instance, isomerization catalyzed by $\mathrm{Rh}(\mathrm{I})$ and $\mathrm{Pd}(\mathrm{II})$ complexes under thermal conditions, ${ }^{8}$ or under visible light irradiation in the presence of cataIytic amounts of [CpFe(arene) $]^{+}$, has been investigated. ${ }^{9}$ There are various mononuclear transition-metal HMDB complexes in which the HMDB ligand is acting as a chelating $\eta^{4}$-diolefin, ${ }^{10}$ while irradiation of $\mathrm{Fe}(\mathrm{CO})_{5}$ with

(1) (a) Greenberg, A.; Liebman, J . F. In Strained Organic Mol ecules; Academic Press: New York, 1978. (b) Wu, H.-P.; Weakley, T. J . R.; Haley, M. M. Organometallics 2002, 21, 4320.

(2) (a) J ohnson, R. P.; Daoust, K. J . J . Am. Chem. Soc. 1996, 118, 7381. (b) Cutman, I.; Potgeiter, J . H. J. Chem. Educ. 1994, 71, 222. (3) van Tamelen, E. E.; Pappas, S. P. J . Am. Chem. Soc. 1963, 85, 3297.

(4) Schäfer, W. Angew. Chem., Int. Ed. Engl. 1966, 5, 669.

(5) (a) Peacock, N. J .; Schuster, G. B. J . Am. Chem. Soc. 1983, 105, 3632. (b) Marcinek, A.J . Phys. Chem. A 1998, 102, 7761.

(6) Oth, J . F. M. Red. Trav. Chim. Pays-Bas 1968, 87, 1185.

(7) Hoffmann, R.; Woodward, R. B. Acc. Chem. Res. 1968, 1, 17.

(8) (a) Dietal, H.; Maitlis, P. J . Chem. Soc., Chem. Commun. 1967, 759. (b) Volger, H.; Hogeveen, H. Recl. Trav. Chim. Pays-Bas 1967, 86, 830

(9) Román, E.; Hernández, S.; Barrera, M. J . Chem. Soc., Chem. Commun. 1984, 1067.

(10) (a) Fischer, E. O.; Kreiter, C. G.; Berngruber, W. Angew. Chem., Int. Ed. Engl. 1967, 6, 634. (b) Mason, R.; Robertson, G. B.; Whimp, P. O. J . Chem. Soc. A 1970, 535. (c) Green, M.; Lewis, B. J. Chem. Soc., Dalton Trans. 1975, 1137.
HMDB produces the HMB complex $\left[\left(\eta^{6}-\mathrm{C}_{6} \mathrm{Me}_{6}\right) \mathrm{Fe}\right.$ $\left.(\mathrm{CO})_{2}\right]_{2} \cdot{ }^{11}$ In rare cases the HMDB moiety has lost its unity, such as in the reaction of $\mathrm{RhCl}_{3} \cdot \mathrm{xH}_{2} \mathrm{O}$ with $\mathrm{HMDB}$, causing a ring contraction to give $\left[\left(\eta^{5}-\mathrm{C}_{5} \mathrm{Me}_{5}\right)-\right.$ $\left.\mathrm{RhCl}_{2}\right]_{2} \cdot{ }^{12}$ However, the coordination chemistry of HMDB with metal clusters has received little attention. We now report that $\mathrm{Os}_{3}(\mathrm{CO})_{10}(\mathrm{NCMe})_{2}$ not only catalyzes the conversion of HMDB to HMB but also causes unusual $\mathrm{C}-\mathrm{H}$ and $\mathrm{C}-\mathrm{C}$ bond activations of the HMDB ligand to form unique cluster complexes.

Treatment of $\mathrm{Os}_{3}(\mathrm{CO})_{10}(\mathrm{NCMe})_{2}$ with $\mathrm{HMDB}$ (4-fold) at room temperature in methylcyclohexane solvent affords a yellow solution with an IR spectrum ${ }^{13}$ similar to that of $\mathrm{Os}_{3}(\mathrm{CO})_{10}\left(\eta^{4}\right.$-cyclodiene) (diene = cyclooctadiene, ${ }^{14}$ cyclohexadiene, ${ }^{15}$ norbornadiene $\left.{ }^{16}\right)$, suggesting that the chelating $\eta^{4}$-diolefin complex $\mathrm{Os}_{3}(\mathrm{CO})_{10}(\mathrm{HMDB})$ (3) is formed. Upon reflux of this mixture under dinitrogen, transformation of HMDB to HMB was observed (path a, Scheme 1).17 This catalytic reaction is in competition with $\mathrm{C}-\mathrm{H}$ bond activation of the HMDB ligand (path $\mathbf{b}$ ) to give the dihydrido vinylmethylidene cluster $(\mu-\mathrm{H})_{2} \mathrm{Os}_{3}(\mathrm{CO})_{9}\left(\mu-\eta^{3}-\mathrm{CH}\left(\mathrm{C}_{6} \mathrm{Me}_{5}\right)\right)(\mathbf{1})^{18}$ and the acetylide cluster $(\mu-\mathrm{H}) \mathrm{Os}_{3}(\mathrm{CO})_{9}\left(\mu_{3}-\eta^{2}-\mathrm{C} \equiv \mathrm{C}\left(\mathrm{C}_{4} \mathrm{Me}_{4} \mathrm{Et}\right)\right)$ (2) ${ }^{19}$ in $15 \%$ and $10 \%$ yields, respectively, after separa-

(11) Fischer, E. O.; Berngruber, W.; Kreiter, C. G. J . Organomet. Chem. 1968, 14, 25.

(12) Maitlis, P. M. Acc. Chem. Res. 1978, 11, 301.

(13) IR (methylcyclohexane, $v(\mathrm{CO})$ ): 2120 (w), 2060 (s), 2036 (s), 2012 (vs), 1996 (sh), 1982 (s), $1956(\mathrm{~m}) \mathrm{cm}^{-1}$.

(14) Tachikawa, M.; Shapley, J . R. J . Organomet. Chem. 1977, 124, C19.

(15) Bryan, E. G.; J ohnson, B. F. G.; Kelland, J . W.; Lewis, J . J Chem. Soc., Chem. Commun. 1976, 254.

(16) Tachikawa, M.; Richer, S. I.; Shapley, J . R. J . Organomet. Chem. 1977, 128, C9.

(17) This catalytic reaction has been followed by ${ }^{1} \mathrm{H}$ NMR spectroscopy (in $\mathrm{C}_{6} \mathrm{D}_{6}$ ) and the degree of $\mathrm{HMDB} / \mathrm{HMB}$ conversion estimated by integration of the respective signals of reactant and product. A $15 \%$ conversion is achieved within $24 \mathrm{~h}$ at $80^{\circ} \mathrm{C}$ with $5 \mathrm{~mol} \%$ concentration of $\mathrm{Os}_{3}(\mathrm{CO})_{10}(\mathrm{NCMe})_{2}$, while the blank test (without adding Os $s_{3}$ cluster) gives only a $2 \%$ conversion.

(18) Anal. Calcd for $\mathrm{C}_{21} \mathrm{H}_{18} \mathrm{O}_{9} \mathrm{Os}_{3}: \mathrm{C}, 25.66 ; \mathrm{H}, 1.83$. Found: C, 26.00; $\mathrm{H}$, 1.94. MS (FAB): $\mathrm{m} / \mathrm{z} 990$ (M+r, 192Os). IR (n-hexane, $v(\mathrm{CO})): 2120$ (w), 2064 (m), 2036 (vs), 2016 (s), 1986 (m), 1958 (m) cm-1. ${ }^{1} \mathrm{H}$ NMR $\left(\mathrm{CDCl}_{3}, 25^{\circ} \mathrm{C}\right): \delta 6.73(\mathrm{~d}, \mathrm{~J}=2 \mathrm{~Hz}, 1 \mathrm{H}), 2.12(\mathrm{~s}, 3 \mathrm{H}), 1.79(\mathrm{~s}, 3 \mathrm{H})$, $1.61(\mathrm{~s}, 3 \mathrm{H}), 1.35(\mathrm{~s}, 3 \mathrm{H}), 0.96(\mathrm{~s}, 3 \mathrm{H}),-17.56(\mathrm{~d}, \mathrm{~J}=2 \mathrm{~Hz}, u-\mathrm{H}),-18.04$ $(\mathrm{s}, \mu-\mathrm{H}) .{ }^{13} \mathrm{C}\left\{{ }^{3} \mathrm{H}\right\} N M R\left(\mathrm{CDCl}_{3}, 25^{\circ} \mathrm{C}\right): \delta 185.0,178.6,176.3,174.7$, 174.1, 171.5, 170.7, 170.5, 166.4 (CO), 147.2, 139.9 (MeC=CMe), 134.7, $92.1(u-\mathrm{CMe}=\mathrm{CMe}), 78.7(u-\mathrm{CH}), 66.3,61.2(\mathrm{MeC}-\mathrm{CMe}), 29.9,12.8$, 10.9, 10.2, $10.0\left(\mathrm{CH}_{3}\right)$. Crystal data for 1: $\mathrm{C}_{21} \mathrm{H}_{16} \mathrm{O}_{9} \mathrm{Os}_{3}, \mathrm{M}_{\mathrm{r}}=982.94$, monoclinic, space group P2 $1 / n, a=14.3985(1) \AA, b=13.9599(1) \AA$, $\mathrm{C}=12.9294(1), \alpha=90^{\circ}, \beta=107.8824(4)^{\circ}, \gamma=90, \mathrm{~V}=2473.28(3) \AA^{3}$, $\mathrm{Z}=4, \rho_{\text {calcd }}=2.640 \mathrm{~g} \mathrm{~cm}^{-3}, \mu=15.420 \mathrm{~mm}^{-1}, \mathrm{~F}(000)=1768, \theta$ range $1.49-27.50^{\circ}, 299$ variables refined with 5673 independent reflections to final $\mathrm{R}$ indices $(I>2 \sigma(I))$ of $\mathrm{R} 1=0.0328$ and $\mathrm{WR} 2=0.0793$, and $\mathrm{GOF}=1.138$. 
Scheme 1
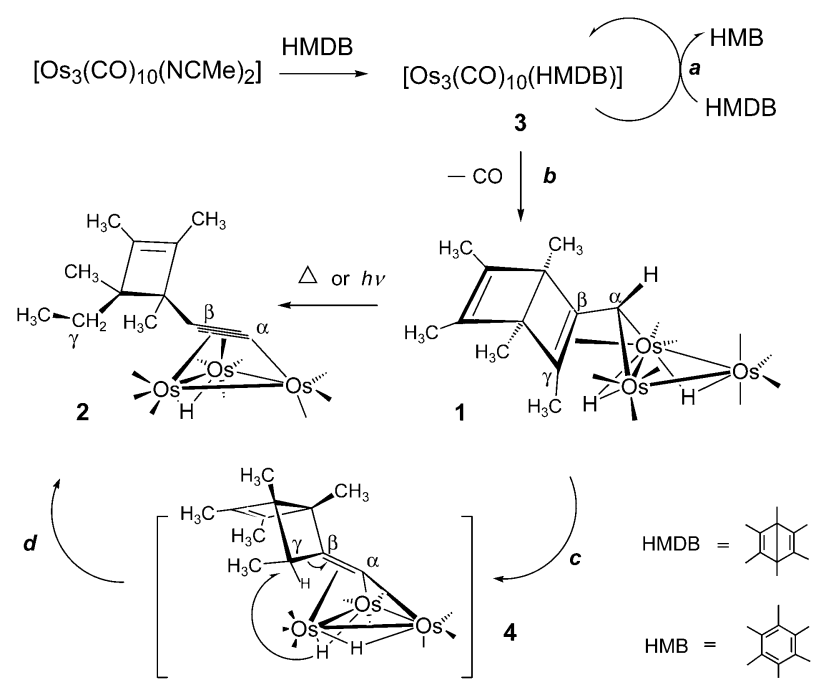

tion by TLC and crystallization. The alternative procedure to improve the yields of $\mathbf{1}$ and $\mathbf{2}$ to 54 and 13\%, respectively, is by adding $\mathrm{HMDB}$ dropwise into a hot $\mathrm{Os}_{3}(\mathrm{CO})_{10}(\mathrm{NCMe})_{2}$ solution. Compound $\mathbf{1}$ is likely the precursor of $\mathbf{2}$, since heating $\mathbf{1}$ produces $\mathbf{2}$ as the major organometallic product. It is worth noting that photoirradiation of $\mathbf{1}$ also leads to $\mathbf{2}$ in $62 \%$ yield, but with no evidence for the formation of arene clusters ${ }^{20}$ (via opening of the Dewar benzene ring), as might be expected.

Organotriosmium cluster systems are known to undergo a variety of transformations in which the organic moiety is changed by proton transfers to and/or from the metal framework, ${ }^{21}$ such as activation of benzene $\mathrm{C}-\mathrm{H}$ bonds to form the benzyne complex $(\mu-\mathrm{H})_{2} \mathrm{Os}_{3}-$ $(\mathrm{CO})_{9}\left(\mu_{3}-\eta^{2}-\mathrm{C}_{6} \mathrm{H}_{4}\right) .{ }^{22}$ Apparently, compound $\mathbf{1}$ is derived from 3 via double $\mathrm{C}-\mathrm{H}$ bond activation of a HMDB methyl group on the triosmium framework, concomitant with a CO loss and a change of the diene bonding mode to an $\eta^{2}$ feature. Nevertheless, direct $\mathrm{C}-\mathrm{H}$ bond activation of the HMDB molecule onto the metal cluster without precoordination cannot be excluded under the thermal conditions. The reaction pathways from $\mathbf{1}$ to $\mathbf{2}$ appear to be greatly complicated, which involve opening of a cyclobutene ring and various hydrogen atom migrations. A plausible mechanism is depicted in paths $\mathbf{c}$ and d of Scheme 1. Presumably, a hydrogen 1,3-shift from the alkylidene carbon $(\alpha)$ to the alkene carbon $(\gamma)$ occurs to generate the $\mu_{3}-\eta^{2}$-vinylidene intermediate 4 , followed by $\mathrm{C}_{\beta}-\mathrm{C}_{\gamma}$ bond scission and hydrogen migration to the

(19) Anal. Calcd for $\mathrm{C}_{21} \mathrm{H}_{18} \mathrm{O}_{9} \mathrm{Os}_{3}: \mathrm{C}, 25.66 ; \mathrm{H}, 1.83$. Found: $\mathrm{C}, 25.20$ $\mathrm{H}, 1.60$. MS (FAB): $\mathrm{m} / \mathrm{z} 990$ [M+, 192Os]. IR (n-hexane, $v(\mathrm{CO})): 2100$ (w), 2072 (vs), 2048 (s), 2012 (vs), 2000 (s), 1978 (m) cm-1. 1H NMR $\left(\mathrm{CDCl}_{3}, 25^{\circ} \mathrm{C}\right): \delta 1.78(\mathrm{~s}, 3 \mathrm{H}), 1.62(\mathrm{~s}, 3 \mathrm{H}), 1.45(\mathrm{~s}, 3 \mathrm{H}), 1.14(\mathrm{~s}, 3 \mathrm{H}$, $\mathrm{Me}), 1.03$ (q, 2H, Et), $0.89(\mathrm{t}, 3 \mathrm{H}, \mathrm{Et}),-22.99$ (s, $\mu-\mathrm{H})$. Crystal data for 2: $\mathrm{C}_{21} \mathrm{H}_{17} \mathrm{O}_{9} \mathrm{Os}_{3}, \mathrm{M}_{\mathrm{r}}=983.95$, monodinic, space group $\mathrm{P} 2_{1} / \mathrm{n}$, a = 9.5373(1) $\AA, b=42.8440(4) \AA, c=12.2112(1) \AA, \alpha=90^{\circ}, \beta=103.2851$ $(5)^{\circ}, \gamma=90^{\circ}, V=4856.16(8) \AA^{3}, Z=8, \rho_{\text {calcd }}=2.692 \mathrm{~g} \mathrm{~cm}^{-3}, \mu=15.707$ $\mathrm{mm}^{-1}, \mathrm{~F}(000)=3544, \theta$ range $1.78-27.50^{\circ}, 596$ variables refined with 11006 independent reflections to final $\mathrm{R}$ indices $(\mathrm{I}>2 \sigma(\mathrm{I}))$ of $\mathrm{R} 1=$ 0.0429 and $w R 2=0.0936$, and GOF $=1.151$

(20) Edwards, A. J .; Leadbeater, N. E.; Lewis, J .; Raithby, P. R. J . Chem. Soc., Dalton Trans. 1995, 3785.

(21) Shriver, D. F.; Kaesz, H. D.; Adams, R. D. The Chemistry of Metal Cluster Complexes; VCH: New York, 1990

(22) (a) Azam, K. A.; Yin, C. C.; Deeming, A. J . J . Chem. Soc., Dalton Trans. 1978, 1201. (b) Yeh, W.-Y.; Kneuper, H.-J .; Shapley, J. R. Polyhedron 1988, 7, 961.

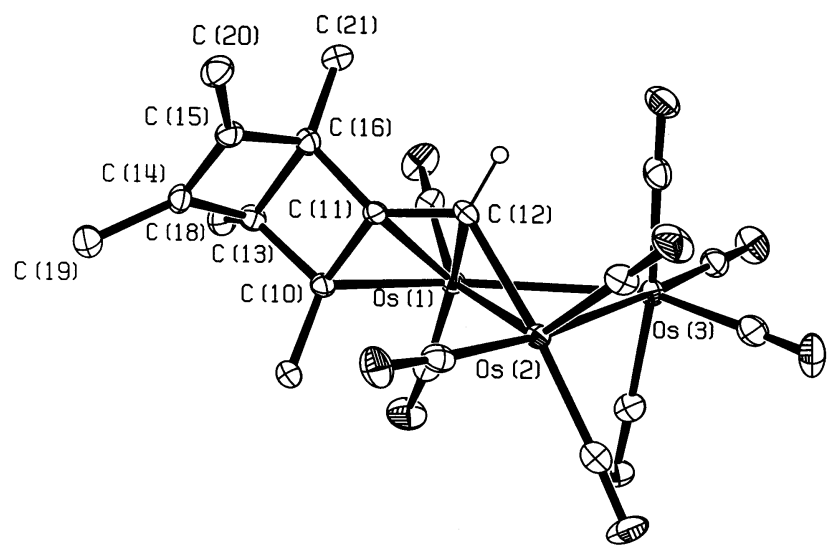

Figure 1. Molecular structure of 1 (ORTEP diagram). Selected bond lengths $(\AA)$ : Os $(1)-O s(2)=2.8730(3)$, Os$(1)-\mathrm{Os}(3)=3.0550(4), \mathrm{Os}(2)-\mathrm{Os}(3)=2.8855(3), \mathrm{Os}(1)-$ $\mathrm{C}(12)=2.250(6), \mathrm{Os}(1)-\mathrm{C}(11)=2.259(6), \mathrm{Os}(1)-\mathrm{C}(10)=$ 2.217(6), Os(2)-C(12) = 2.141(6), $\mathrm{C}(10)-\mathrm{C}(11)=1.489(8)$, $\mathrm{C}(11)-\mathrm{C}(12)=1.378(9), \mathrm{C}(10)-\mathrm{C}(13)=1.549(9), \mathrm{C}(13)-$ $\mathrm{C}(14)=1.524(9), C(13)-C(16)=1.583(9), C(14)-C(15)=$ $1.345(9), C(15)-C(16)=1.510(9), C(11)-C(16)=1.533(9)$. Selected bond angles (deg): Os(1)-Os(2)-Os(3) = 64.080(9), Os(1)-Os(3)-Os(2) = 57.761(8), Os(2)-Os(1)-Os(3) = 58.158(8), Os(1)-C(12)-Os(2) = 81.7(2), Os(1)-C(12)$\mathrm{C}(11)=72.6(4), \mathrm{Os}(2)-\mathrm{C}(12)-\mathrm{C}(11)=121.6(5), \mathrm{C}(12)-$ $C(11)-C(10)=129.0(6), C(12)-C(11)-C(16)=134.7(6)$, $C(10)-C(11)-C(16)=93.4(5), C(11)-C(16)-C(13)=87.3-$ (5), $C(16)-C(13)-C(10)=89.2(5), C(13)-C(10)-C(11)=$ 90.1(5), C(13) $-C(14)-C(15)=93.5(5), C(14)-C(15)-C(16)$ $=95.5(5), C(15)-C(16)-C(13)=85.1(5), C(16)-C(13)-$ $C(14)=85.8(5), C(11)-C(16)-C(15)=109.1(5), C(10)-$ $\mathrm{C}(13)-\mathrm{C}(14)=111.3(5), \mathrm{C}(13)-\mathrm{C}(14)-\mathrm{C}(19)=132.0(6)$, $\mathrm{C}(15)-\mathrm{C}(14)-\mathrm{C}(19)=134.4(6), \mathrm{C}(14)-\mathrm{C}(15)-\mathrm{C}(20)=135.1-$ (6), $C(16)-C(15)-C(20)=129.4(6)$.

$\gamma$-carbon to afford 2. Complexes containing a $\mu_{3}-\eta^{2}-$ vinylidene ligand are known in many cluster systems. ${ }^{21,23}$ Besides, equilibration of vinylidene and acetylide species has been postulated for chemisorption of acetylene on the Pt(111) surface. ${ }^{24}$

The ${ }^{1} \mathrm{H}$ NMR spectrum of $\mathbf{1}$ displays five singlets in the range $\delta$ 2.12-0.96 for the inequivalent methyl groups and a $1 \mathrm{H}$ doublet at $\delta 6.73$ for the alkylidene proton, which is coupled with the bridging hydride resonance at $\delta-17.56(\mathrm{~J}=2 \mathrm{~Hz})$, while the other bridging hydride appears as a singlet at $\delta-18.04$. The molecular structure of $\mathbf{1}$ is depicted in Figure 1 . The two hydride ligands were not located but are believed to span the Os(1)-Os(3) and Os(1)-Os(2) edges, where the Os(1)-Os(3) distance of 3.0550(4) $\AA$ is significantly longer than the other intermetallic distances Os(1)$\mathrm{Os}(2)=2.8730(3) \AA$ and Os(2)-Os(3) $=2.8855(3) \AA$. The coordinated portion of the organic ligand can be described as a vinylmethylidene. The methylidene carbon $\mathrm{C}(12)$ bridges the Os(1)-Os(2) edge asymmetrically with the bond lengths $\mathrm{C}(12)-\mathrm{Os}(2)=2.141(6) \AA$ and $\mathrm{C}(12)-$ $\mathrm{Os}(1)=2.250(6) \AA$. The dihedral angle between the triosmium plane and the Os(1)-C(12)-Os(2) plane is $108.3^{\circ}$. The vinyl $\mathrm{C}(10)=\mathrm{C}(11)$ group is coordinated to Os(1) in the exo side, with a $\mathrm{C}(10)-\mathrm{Os}(1)$ distance of

(23) (a) Green, M.; Orpen, A. G.; Schaverien, C. J J Chem. Soc. Chem. Commun. 1984, 37. (b) Evans, J .; J ohnson, B. F. G.; Lewis, J .; Matheson, T. W. J . Organomet. Chem. 1975, 97, C16.

(24) Manojlović-Muir, L.; Muir, K. W.; Rashidi, M.; Schoettel, G.; Puddephatt, R. J . Organometallics 1991, 10, 1719. 


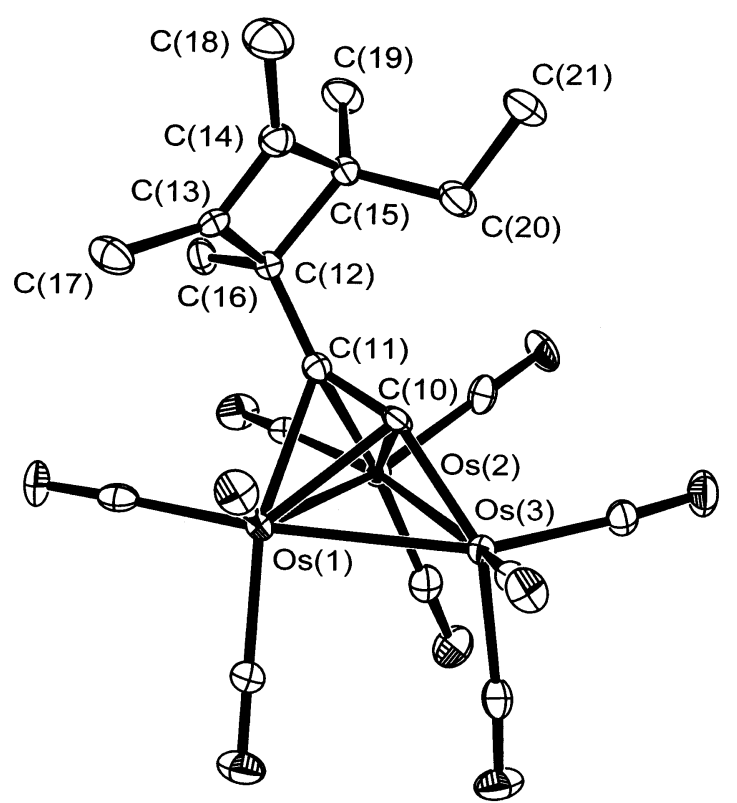

Figure 2. Molecular structure of $\mathbf{2}$ (ORTEP diagram). Selected bond lengths $(\AA)$ : Os $(1)-\operatorname{Os}(2)=2.8337(6)$, Os$(1)-\mathrm{Os}(3)=2.8322(5), \mathrm{Os}(2)-\mathrm{Os}(3)=2.8433(6), \mathrm{Os}(1)-$ $\mathrm{C}(10)=2.255(9), \mathrm{Os}(1)-\mathrm{C}(11)=2.28(1), \mathrm{Os}(2)-\mathrm{C}(10)=$ 2.25(1), Os(2)- $\mathrm{C}(11)=2.30(1), \mathrm{Os}(3)-\mathrm{C}(10)=1.98(1)$, $\mathrm{C}(10)-\mathrm{C}(11)=1.32(1), \mathrm{C}(11)-\mathrm{C}(12)=1.50(1), \mathrm{C}(12)-\mathrm{C}(13)$ $=1.54(2), C(13)-C(14)=1.34(1), C(14)-C(15)=1.51(2)$, $\mathrm{C}(15)-\mathrm{C}(12)=1.63(1)$. Selected bond angles (deg): Os(1)Os(2)-Os(3) = 59.85(1), Os(1)-Os(3)-Os(2) = 59.91(1), Os(2) $-\mathrm{Os}(1)-\mathrm{Os}(3)=60.24(1)$, Os(1) $\mathrm{C}(10)-\mathrm{Os}(2)=77.9(3)$, $\mathrm{Os}(1)-\mathrm{C}(11)-\mathrm{Os}(2)=76.4(3), \mathrm{Os}(3)-\mathrm{C}(10)-\mathrm{C}(11)=152.4-$ (8), Os(1)-C(11)-C(12) = 133.5(7), Os(2)-C(11)-C(12) = 133.5(7), $\mathrm{C}(10)-\mathrm{C}(11)-\mathrm{C}(12)=142.5(9), \mathrm{C}(11)-\mathrm{C}(12)-$ $C(13)=116.8(9), C(12)-C(13)-C(14)=95.2(9), C(13)-$ $\mathrm{C}(14)-\mathrm{C}(15)=95.6(9), \mathrm{C}(14)-\mathrm{C}(15)-\mathrm{C}(12)=85.4(8)$, $C(15)-C(12)-C(13)=83.6(7)$.

2.217(6) $\AA$ and C(11)-Os(1) distance of 2.259(6) $\AA$. The Dewar benzene framework remains intact, such that the two cycl obutene rings are each planar with a dihedral angle of $109.7^{\circ}$ between the two planes and the $\mathrm{C}(10)-$ $C(11), C(13)-C(16)$, and $C(14)-C(15)$ edges are parallel to each other, giving a ladder-shaped (or trapezoid) configuration.
The IR absorptions in the carbonyl region of $\mathbf{2}$ show a pattern similar to that recorded for $\left[(u-\mathrm{H}) \mathrm{Os}_{3}(\mathrm{CO})_{9-}\right.$ $\left.\left(\mu_{3}-\eta^{2}-\mathrm{C} \equiv \mathrm{CR}\right)\right]{ }^{25}$ The ${ }^{1} \mathrm{H}$ NMR spectrum presents four singl ets in the range $\delta$ 1.78-1.14 for the methyl groups, a $2 \mathrm{H}$ quartet at $\delta 1.03$ and a $3 \mathrm{H}$ triplet at $\delta 0.89$ for the ethyl group, and a singlet at $\delta-22.99$ for the bridging hydride. The molecular structure of $\mathbf{2}$ is shown in Figure 2. The bridging hydride ligand was not located but is believed to span the Os(1)-Os(2) edge. The overall molecule consists of a triangular $\mathrm{Os}_{3}(\mathrm{CO})_{9}$ moiety, which is capped on one face by a $\mu_{3}-\eta^{2}$-cyclobutenylacetylide ligand. The $\mathrm{Os}_{3}$ triangle is nearly isosceles, with Os$(1)-\mathrm{Os}(2)=2.8337(6) \AA$, Os $(1)-\mathrm{Os}(3)=2.8322(5) \AA$, and $\mathrm{Os}(2)-\mathrm{Os}(3)=2.8433(6) \AA$. The acetyl ide $\mathrm{C}(10) \equiv \mathrm{C}(11)$ group formally forms a $\sigma$ bond to Os(3) and $\pi$-bonds to the atoms $\mathrm{Os}(1)$ and $\mathrm{Os}(2)$. The Os(3), C(10), C(11), and $\mathrm{C}(12)$ atoms are about coplanar (torsion angle $178.1^{\circ}$ ), with the bond angles Os(3)-C(10)-C(11) $=152.4(8)^{\circ}$ and $\mathrm{C}(10)-\mathrm{C}(11)-\mathrm{C}(12)=142.5(9)^{\circ}$. The cyclobutene ring is slightly twisted, as indicated by the torsion angles $\mathrm{C}(12)-\mathrm{C}(13)-\mathrm{C}(14)-\mathrm{C}(15)=3.06^{\circ}$ and $\mathrm{C}(17)-$ $C(13)-C(14)-C(18)=3.69^{\circ}$. The alkyl groups connected to the $C(12)$ and $C(15)$ atoms are essentially eclipsed, which should cause considerable steric repulsions and might account for the lengthened $C(12)-C(15)$ singlebond distance of $1.63(1) \AA$ (cf. $C(13)-C(16)=1.583(9)$ $\AA$ in 1).

In summary, the transformation from hexamethyl Dewar benzene to a cyclobutenylacetylide moiety in $\mathbf{2}$ is unprecedented and of interest within the context of the chemistry of strained hydrocarbons. It may provide an attractive general strategy for the activation of related bicyclodiene systems, which are applicable to organic synthesis.

Acknowledgment. We are grateful for support of this work by the National Science Council of Taiwan.

Supporting Information Available: Complete tables of crystallographic data, positional parameters, bond lengths, and bond angles of $\mathbf{1}$ and $\mathbf{2}$. This material is available free of charge via the Internet at http://pubs.acs.org.

OM030281U 1769. 